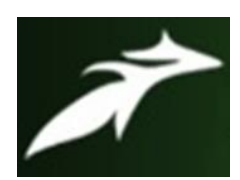

HARIHARA TRIPATHY et al, International Journal of Advances in Agricultural Science and Technology,

Vol.8 Issue.7, July-2021, pg. 24-33

\title{
KNOWLEDGE OF FARMERS TOWARDS PRIVATIZATION OF AGRICULTURAL EXTENSION SERVICES IN GANJAM DISTRICT OF ODISHA
}

\author{
HARIHARA TRIPATHY ${ }^{1}$; DIPAK KUMAR BOSE ${ }^{2}$; JAHANARA ${ }^{3}$ \\ ${ }^{1}$ Research Scholar, Department of Agricultural Extension and Communication, SHUATS, Allahabad, \\ Uttar Pradesh, India \\ ${ }^{2}$ Associate Professor, Department of Agricultural Extension and Communication, SHUATS, \\ Allahabad, Uttar Pradesh, India \\ ${ }^{3}$ Professor and Head, Department of Agricultural Extension and Communication, SHUATS, \\ Allahabad, Uttar Pradesh, India \\ DOI: 10.47856/ijaast.2021.v08i7.003
}

\begin{abstract}
A vast country like India cannot afford to ignore ever increasing role of PAES carried out by many individuals and agencies like Agricultural consultants, group of progressive farmers, mass media like newspapers, TV, agricultural magazines, non-government organizations, private sector banks etc. Today the challenge is not the same. Finding better market for surplus produced decides Indian agriculture. Limited rescores in extension compel to look for the support of other extension system, thus opened thinking on private extension. The present extension system has ultimatum for reshaping and strengthening the structural design for the delivery of agricultural technology and services as needed by the farming community. The study was conducted in Ganjam District of Odisha purposively for investigating socio-economic status and the association of independent variables with farmers' knowledge towards Privatization of Agricultural Extension Services. Descriptive research design was used for the present study. A total of 120 respondents were selected purposively as a sample for the present investigation. The data was collected by using pretested schedule and analyzed using appropriate statistical tools. Karl Pearson's Co-efficient of Correlation test was applied to find out the association between farmers knowledge with independent variables. The major findings of the study were the socio-economic status of the respondents was found to be of medium level, the knowledge of the respondents towards PAES had significant association with the Age, Annual income, Education, Land holding Mass Media Exposure, Extension contact, Risk orientation, and scientific orientation. From the study, it is clear that PAES has become essential in our country to increase the competitiveness in the world and give justice to our farmers. At the same time, it requires great caution about problems and constraints emerged in PAES. Keeping this points stated above the present study was undertaken in Ganjam district of Odisha with the following objectives:

$\star$ To determine the socio-economic status of the respondents.

$\star$ To ascertain the association between independent variables and knowledge of farmers towards Privatization of Agricultural Extension Service (PAES).
\end{abstract}

Keywords: Knowledge, Privatization of Agricultural Extension Services (PAES), Farmers. 


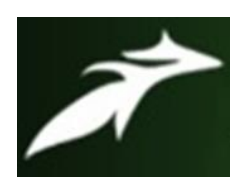

HARIHARA TRIPATHY et al, International Journal of Advances in Agricultural Science and Technology, Vol.8 Issue.7, July-2021, pg. 24-33

ISSN: 2348-1358

Impact Factor: 6.057

NAAS Rating: 3.77

\section{INTRODUCTION}

India is a large country with a geographical area 329 million ha of which 69 million ha (22.5 per cent) are under forest, 42 million ha are (13.7 per cent) not available for cultivation and about 28 million ha (9.4 per cent) are not under cultivation. One hundred and forty-two million ha of land are under cultivation of which only 53 million ha are irrigated. Agriculture is the most important sector of the Indian economy. It contributes about 25 per cent of the total Gross Domestic Product (GDP) and provides employment to about 67 per cent of the working population of the country. The food grain production of the country has increased fourfold during the last five decades. However, despite being self-sufficient in the production of food grains farmers are unable to obtain remunerative prices for their farm produce. With the sustained efforts of the Government of India (GOI), there has been continuous increase in quantity and quality of farm produce due to the provision of farm support services especially to small/marginal farmers.

India chases the world in reforming its extension and research systems. There are many developing countries where extension and advisory services reforms are occurring globally. India is one of the developing country where decentralization of the extension systems carried out based on agro-ecological conditions and access to markets. Since the nature of Indian agriculture was changing with shrinkage of resources like land, water and human resource for extension system, changes in demand and consumption pattern of the Indian population, changes in the farming system and farming pattern, decline in the public investments towards agriculture, International developments like Globalization, Liberalization and Privatization. All these changes drag the researchers and policymakers to reform and reshape the public extension system as a public private partnership entity where the government works along with or distribute a part of work activities to the private sector for effective extension delivery system. India with vast population under marginal and small land holdings some objections may confronted from small and marginal farmers of the nation. 


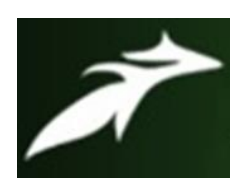

HARIHARA TRIPATHY et al, International Journal of Advances in Agricultural Science and Technology, Vol.8 Issue.7, July-2021, pg. 24-33

ISSN: 2348-1358

Impact Factor: 6.057

NAAS Rating: 3.77

\section{RESEARCH METHODOLOGY}

This section describes the approaches and methods employed for data collection and analysis. The first sub-section of this chapter presents the description of the study area. Then the details of methodology used to conduct the overall study were discussed in subsequent sub-sections. Descriptive research design was used for the present study. Descriptive research design is used to describe characteristics of a population or phenomenon being studied. Descriptive research design is a scientific method which involves observing and describing the behavior of the subject without influencing it in anyway. Odisha state was selected purposively because more public-private sectors are working for Upliftment of the Socio-economic condition of the rural families. The Ganjam District was selected purposively for research investigation because it is one of the largest districts in Odisha and there are so many private organizations providing extension services on little bit payment basis. There are total 22 blocks in Ganjam district of Odisha, out of which Purusottampur block have been selected purposively on the basis of maximum area under progressive farmers with the help of KVK. A complete list of all the villages were major farmers involved with privatization agriculture extension services in consultation with the personnel of revenue and agriculture department from the identified block. From list prepared, 6 villages from Purusottampur block were selected on the basis of maximum farmers involved with agriculture sector and progressive farmers with the help of Agriculture officer. Randomly 120 number of farmers were selected with the help of village Sarpanch and agriculture supervisor of respective village (VLW) based on involvement in agriculture and Progressive farmers. The Primary data was collected with the help of personal interview technique with the help of interview schedule with especially objectives, focused study. Secondary data was collected from library, journals, books, papers, and other materials related to study. Quantitative data collected from the Household survey were analyzed using descriptive statistical methods. The responses to the raw quantitative data were coded and stored using Microsoft Excel spreadsheet in order to avoid respondent anonymity. They were summarized while qualitative responses were tallied and finally prioritized in order to determine trends and patterns in the data and draw conclusions. It were also described, 


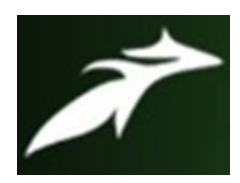

HARIHARA TRIPATHY et al, International Journal of Advances in Agricultural Science and Technology,

Vol.8 Issue.7, July-2021, pg. 24-33

ISSN: 2348-1358

Impact Factor: 6.057

NAAS Rating: 3.77

analyzed and interpreted on the spot during data collection to avoid missing of relevant information.

RESULTS AND DISCUSSIONS

Title Table-1: Socio-economic profile of the respondents.

\begin{tabular}{|c|c|c|c|c|}
\hline Sl.no. & \multicolumn{2}{|c|}{ Socio-Economic Profile of the Respondents } & Frequency & Percentage \\
\hline \multirow[t]{3}{*}{1.} & \multirow[t]{3}{*}{ Age } & Low (20 -35 years) & 18 & 15.00 \\
\hline & & Medium (36-55 years) & 59 & 49.17 \\
\hline & & High (Above 55 years) & 43 & 35.83 \\
\hline \multirow[t]{3}{*}{2.} & \multirow[t]{3}{*}{ Annual Income } & Low (Up to 1lakhs) & 15 & 12.50 \\
\hline & & Medium (1-3 lakhs) & 42 & 35.00 \\
\hline & & High (Above 3 lakhs) & 63 & 52.50 \\
\hline \multirow[t]{6}{*}{3.} & \multirow[t]{6}{*}{ Education } & Illiterate & 43 & 35.83 \\
\hline & & Primary & 8 & 6.67 \\
\hline & & Upper primary & 16 & 13.33 \\
\hline & & Secondary & 34 & 28.34 \\
\hline & & Higher secondary & 4 & 3.33 \\
\hline & & Graduate \& Above & 15 & 12.50 \\
\hline \multirow[t]{3}{*}{4.} & \multirow[t]{3}{*}{ Land Holding } & Low (0-5Acre) & 36 & 30.00 \\
\hline & & Medium (5-10 Acre) & 44 & 36.67 \\
\hline & & High (10 Above) & 40 & 33.33 \\
\hline \multirow[t]{3}{*}{5.} & \multirow{3}{*}{$\begin{array}{c}\text { Mass Media } \\
\text { Exposure }\end{array}$} & Low (5-8) & 22 & 18.33 \\
\hline & & Medium (9-11) & 50 & 41.67 \\
\hline & & High (11 Above) & 48 & 40.00 \\
\hline \multirow[t]{3}{*}{6.} & \multirow[t]{3}{*}{ Extension Contact } & Low (5-8) & 41 & 34.17 \\
\hline & & Medium (9-11) & 57 & 47.50 \\
\hline & & High (11 Above) & 22 & 18.33 \\
\hline
\end{tabular}




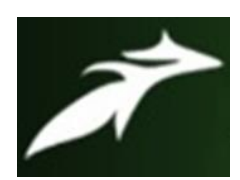

HARIHARA TRIPATHY et al, International Journal of Advances in Agricultural Science and Technology, Vol.8 Issue.7, July-2021, pg. 24-33

ISSN: 2348-1358

Impact Factor: 6.057

NAAS Rating: 3.77

\begin{tabular}{|c|c|c|c|c|}
\hline 7. & Risk orientation & Low (10-13) & 14 & 11.67 \\
\cline { 3 - 5 } & & Medium (14-16) & 74 & 61.67 \\
\cline { 3 - 5 } & & High (16 Above) & 32 & 26.66 \\
\hline 8. & Scientific orientation & Low (11-13) & 5 & 4.17 \\
\cline { 3 - 5 } & & Medium (13-16) & 77 & 64.16 \\
\cline { 3 - 5 } & & High (16 Above) & 38 & 31.67 \\
\hline
\end{tabular}

From the table-1. The results depicted as followed:

Majority of respondents belonged to Middle age group. This group alone constitutes 49.17 per cent of the total sample. This finding is in the line with the findings of Kumari (2012) who reported that higher per cent of the respondents were in Middle age group.

Majority of respondents belonged to high categories i.e. above 3 lakhs Annual Income. This group alone constitutes 52.50 per cent of the total sample. This finding is in the line with the findings of Kushwaha (2018) who reported that higher per cent of the respondents were belongs to high category of annual income.

Majority of the respondents were illiterate. Out of the total 120 respondents, 35.83 percent of the respondents were illiterate. This finding is in the line with the findings of Kumari (2012) who reported that higher per cent of the respondents were in illiterate category.

Majority of the respondents were medium level of land holding capacity. Out of the total 120 respondents; 36.67 per cent farmers possessed medium amount of land holding (510 acres. This finding is in the line with the findings of Kunchala (2012) who reported that medium percent of the respondents were in medium category (5-10acres).

Out of the total 120 respondent's majority of farmers belonged to the medium level of mass media exposure. This group alone constitutes 41.67 per cent of the total sample. Similar results were obtained by Borole (2010), Dandardale (2010) and Kunchala (2012).

Majority of respondents belonged to the medium level of Extension Contact. This group alone constitutes 47.50per cent of the total sample. Similar results were obtained by Borole (2010). 


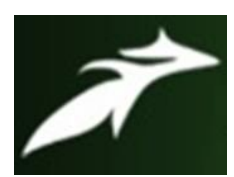

HARIHARA TRIPATHY et al, International Journal of Advances in Agricultural Science and Technology, Vol.8 Issue.7, July-2021, pg. 24-33

ISSN: 2348-1358

Impact Factor: 6.057

NAAS Rating: 3.77

Majority of respondents belonged to the medium level of risk orientation capacity. This group alone constitutes 61.67per cent of the total sample. Similar results were obtained by Pathak (1998), Saravanan (2000), Bhatt (2006), Borole (2010) and Kunchala (2012).

Majority of respondents belonged to the medium level of scientific orientation capacity. This group alone constitutes 64.16per cent of the total sample. Similar results were obtained by Pandya (1998), Bhatt (2006), Borole (2010) and Kunchala (2012).

Table 2: Knowledge of the respondents towards PAES.

[Fully correct (F.P.), Partially correct (P.P.), Not correct (N.P.) Frequency (F), Percentage (P \%).]

\begin{tabular}{|c|l|c|c|c|}
\hline S1. & \multicolumn{1}{|c|}{ STATEMENTS } & \multicolumn{3}{l|}{ KNOWLEDGE LEVEL OF FARMERS } \\
\cline { 3 - 5 } no. & \multicolumn{1}{|c|}{ F.P. F (\%) } & P.P. F (\%) & N.P. F (\%) \\
\hline 1 & $\begin{array}{l}\text { PAES agencies have expertise for the } \\
\text { diagnosis of various kind of pest and diseases. }\end{array}$ & $21(17.50)$ & $49(40.83)$ & $50(41.66)$ \\
\hline 2 & $\begin{array}{l}\text { PAES agencies have their own laboratory for } \\
\text { testing soil, water. }\end{array}$ & $8(6.66)$ & $41(34.16)$ & $71(59.16)$ \\
\hline 3 & PAES agencies have transportation facilities. & $25(20.83)$ & $22(18.33)$ & $73(60.83)$ \\
\hline 4 & $\begin{array}{l}\text { PAES give information on different aspects of } \\
\text { cultivation of crops including soil } \\
\text { management, water management, weed } \\
\text { management, storage. }\end{array}$ & $60(50)$ & $51(42.50)$ & $9(7.50)$ \\
\hline 5 & $\begin{array}{l}\text { PAES give information on newly released and } \\
\text { suitable varieties for the area. }\end{array}$ & $44(36.66)$ & $62(51.66)$ & $14(11.66)$ \\
\hline 6 & PAES give machineries on rent \& repair. & $3(2.50)$ & $47(39.16)$ & $70(58.33)$ \\
\hline 7 & PAES give seed ling of plantation crops. & $18(15)$ & $82(68.33)$ & $20(16.66)$ \\
\hline 8 & $\begin{array}{l}\text { PAES has store house facilities for keeping } \\
\text { the farmers produce safe. }\end{array}$ & $6(5)$ & $63(52.50)$ & $51(42.50)$ \\
\hline 9 & $\begin{array}{l}\text { PAES provide demand driven extension } \\
\text { services. }\end{array}$ & $4(3.33)$ & $84(70)$ & $30(25)$ \\
\hline 10 & $\begin{array}{l}\text { PAES provide high yielding varieties, seeds of } \\
\text { different crops. }\end{array}$ & $69(57.50)$ & $45(37.50)$ & $6(5)$ \\
\hline 11 & PAES provide information on credit facilities. & $33(27.50)$ & $51(42.50)$ & $36(30)$ \\
\hline 12 & $\begin{array}{l}\text { PAES provide information on prices of } \\
\text { different commodities in different markets. }\end{array}$ & $38(31.66)$ & $61(50.83)$ & $21(17.50)$ \\
\hline
\end{tabular}




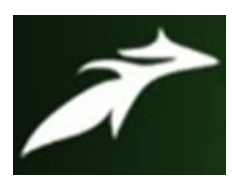

HARIHARA TRIPATHY et al, International Journal of Advances in Agricultural Science and Technology, Vol.8 Issue.7, July-2021, pg. 24-33

ISSN: 2348-1358

Impact Factor: 6.057

NAAS Rating: 3.77

\begin{tabular}{|c|l|c|c|c|}
\hline 13 & $\begin{array}{l}\text { PAES provide information on various kind of } \\
\text { incentives in farming. }\end{array}$ & $41(34.16)$ & $67(55.83)$ & $12(10)$ \\
\hline 14 & $\begin{array}{l}\text { PAES provide insecticides pesticide/ } \\
\text { weedicides, fertilizers to farmers. }\end{array}$ & $109(90.83)$ & $8(6.66)$ & $3(2.50)$ \\
\hline 15 & $\begin{array}{l}\text { PAES provide latest agricultural tools and } \\
\text { implements. }\end{array}$ & $61(50.83)$ & $57(47.50)$ & $2(1.66)$ \\
\hline 16 & $\begin{array}{l}\text { PAES provide solution to specific problems } \\
\text { regarding crop cultivation. }\end{array}$ & $70(58.33)$ & $48(40)$ & $2(1.66)$ \\
\hline 17 & $\begin{array}{l}\text { PAES provide up to date information } \\
\text { regarding pest and disease management of } \\
\text { crops. }\end{array}$ & $80(66.66)$ & $39(32.50)$ & $1(0.83)$ \\
\hline 18. & $\begin{array}{l}\text { PAES provides information on organic } \\
\text { farming. }\end{array}$ & $27(22.50)$ & $84(70)$ & $9(7.50)$ \\
\hline
\end{tabular}

Table 3: Overall Knowledge level of the Respondents towards PAES. $n=120$

\begin{tabular}{|c|c|c|c|}
\hline Sl. No. & \multirow{2}{*}{$\begin{array}{l}\text { Knowledge of farmers } \\
\text { towards PAES Categories }\end{array}$} & \multicolumn{2}{|c|}{ Total Respondents } \\
\cline { 3 - 4 } & & Frequency & Percentage \\
\hline $\mathbf{1}$ & Low & 29 & 24.17 \\
\hline $\mathbf{2}$ & Medium & 55 & 45.83 \\
\hline $\mathbf{3}$ & High & 36 & 30.00 \\
\hline & Total & 120 & 100.00 \\
\hline
\end{tabular}

From the table 3.the results depicted as followed:

The data presented in above table reveals that majority of respondents belonged to the medium level knowledge group. This group alone constitutes 45.83 per cent of the total sample. A considerable number of respondents 30.00per cent were belonged to the high level knowledge group and 24.17per cent respondents were belonged to the low level knowledge group. The above finding was in conformity with research finding of Ajieh (2014). 


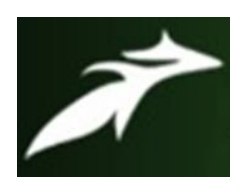

HARIHARA TRIPATHY et al, International Journal of Advances in Agricultural Science and Technology, Vol.8 Issue.7, July-2021, pg. 24-33

ISSN: 2348-1358

Impact Factor: 6.057

NAAS Rating: 3.77

Table 4: Association between Independent Variables and Knowledge of Farmers towards PAES. $n=120$.

\begin{tabular}{|c|c|c|}
\hline Sl.no. & Characteristics & 'r' value \\
\hline 1. & Age & $0.926^{*}$ \\
\hline 2. & Annual income & $0.328^{*}$ \\
\hline 3. & Education & $0.230^{* *}$ \\
\hline 4. & Land holding & $0.260^{*}$ \\
\hline 5. & Mass Media Exposure & $0.751^{*}$ \\
\hline 6. & Extension contacts & $0.670^{*}$ \\
\hline 7. & Risk orientation & $0.999^{*}$ \\
\hline 8. & Scientific orientation & $0.213^{* *}$ \\
\hline
\end{tabular}

* Significant at $1 \%$ level of probability

** Significant at $5 \%$ level of probability

NS = Non-Significant

The above Table- 4 indicates that, the Association between Independent Variables and Knowledge of Farmers by applying Karl Pearson's Co-efficient of Correlation. $1^{\text {st }}$ of all The co-efficient of co-relation between knowledge level of respondents towards PAES and their socio-economic profile was calculated. After that calculated values were compared with tabulated co-efficient of co-relation value .Then this results which clearly indicates that selected characteristics of farmers i.e. Age, Annual income, Land holding Mass Media Exposure, Extension contacts and Risk orientation had positive and highly significant relationship at 0.01 level of probability with Knowledge level of farmers towards PAES Whereas, Education and Scientific orientation had positive significant relationship at 0.05 percent level of probability with Knowledge level of farmers towards PAES .

\section{$\underline{\text { Conclusion }}$}

It was concluded that the socio-economic status of the respondents constitutes medium level. There is a positive association between knowledge of the respondents and independent variables like Age, Annual income, Education, Land holding Mass Media 


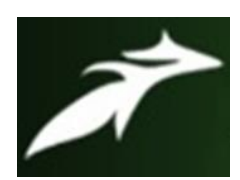

HARIHARA TRIPATHY et al, International Journal of Advances in Agricultural Science and Technology, Vol.8 Issue.7, July-2021, pg. 24-33

ISSN: 2348-1358

Impact Factor: 6.057

NAAS Rating: 3.77

Exposure, Extension contacts Risk orientation and Scientific orientation. The public extension system is over burdened with numerous activities and there should be some phase wise shifting to private sector for effective implementation of essential extension services. From the study, it is clear that Privatization of Agricultural Extension Services has become essential in our country to increase the competitiveness in the world and give justice to our farmers. At the same time, it requires great caution about problems and constraints emerged in privatization of agricultural extension services.

\section{References}

[1]. Adejo, P.E., Okwu, O.J. and Ibrahim, M.K. (2012). Challenges and prospects of privatization of agricultural extension service delivery in Nigeria. Journal of Agricultural Extension and Rural Development, 4 (3), pp. 63 - 68.

[2]. Ajieh and Patrick, C. (2014).Farmers' knowledge and perception of privatization and commercialization of agricultural extension services in delta state, Nigeria, Indian J. Agric. Res.., 48(1): 35 - 40.

[3]. Bawa, D.B., Ani, A.O. and Noah, H.S. (2009). Perception of privatization and commercialization of agricultural extension services in Adamawa state, Nigeria. American-Eurosian Journal of Sustainable Agriculture. 3(3): 375- 380.

[4]. Bhatt, P. M. (2006). Effect of mass media exposure on dairy farmers regarding animal husbandry practices, $\mathrm{Ph}$. D., Thesis, AAU, Anand.

[5]. Bhatt, S.H. (2005). A study on technological gaps and constraints in cultivation of rice in Jammu and Kashmir.Ph.D. (Ag.). Thesis, JNKVV, Jabalpur.

[6]. Borole, P. K. (2010). Attitude of demonstrated paddy growers towards SRI technique of paddy crop, M. Sc. (Agri.) Thesis (Unpublished), AAU, Anand.

[7]. Darandale, A. D. (2010). Attitude of tribal farmers towards organic farming practices in maize crop, M. Sc. (Agri.) Thesis AAU, Anand.

[8]. Gautam et al, (2006) Agriculture Extension in India: A Journey since 1952.

[9]. Kaur, J., Peer, Q.J.A., Malik, J.S. and Shehrawat, P.S. (2015). Knowledge of Farmers about Privatization of Agricultural Extension Services and the factors influencing it. Economic Affairs: 60 (2): 219-224.

[10].Kaur, J., Shehrawat, P.S. and Peer, Q.J.A. (2014), Attitude of Farmers towards Privatization of Agricultural Extension Services, Agric. Sci. Digest., 34(2): 81- 86.

[11].Kumar, P. and Nain, M.S., (2014). A critical analysis of the privatization of Agricultural Extension Services. Indian Journal of Social Research, 55 (3): 427435. 


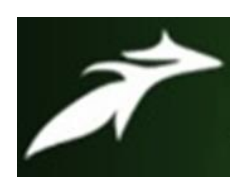

HARIHARA TRIPATHY et al, International Journal of Advances in Agricultural Science and Technology, Vol.8 Issue.7, July-2021, pg. 24-33

ISSN: 2348-1358

Impact Factor: 6.057

NAAS Rating: 3.77

[12].Kumari, Y.S. (2012). A study on the opinion of farmers on the privatization of agricultural Extension services in A.P. M.Sc. (Ag) Thesis Submitted to Orissa University Of Agriculture And Technology Bhubaneswar.

[13].Kunchala, K. D.; Patel, J. K. and Desai, C. P. (2012) Advantages of private extension service and its correlates with attitude toward private extension service. Guj. J. Ext. Edu., 23: 177-179.

[14].Kushwaha, N. (2018). A Study on Attitude of Farmers towards Privatization of Agricultural Extension Services. M.Sc. (Ag) Thesis Submitted to RVSKVV, Gwalior (M.P.).

[15].Naidu, J.Y.N. and Bose, D.K. (2016). Farmers' View on Privatization of Agricultural Extension Services in Ananthapur District (A.P.), International Journal of Agricultural Science and Research, 6(4): 35-44.

[16].Pandya, R. D. (2004) A Scales to measure the attitude towards the privatization of extension service. Guj. J. Ext. Edu., XV pp: 66-70.

[17].Rivera, M.W. and Cary, W.J. (2000). Privatizing agricultural extension, In: Improving Agricultural Extension - A Reference Manual, Food and Agricultural Organization, United States, Rome: 204-210.

[18].Saravanan, R. (1999). A study on privatization of agricultural extension service. M.Sc. Thesis. University of Agricultural Sciences, Bangalore, India.

[19]. Sarvanan, R. (2001): Privatization of Agricultural Extension. In R Chandra Sekhara (Ed.) Private Extension in India: Myths, realities, apprehensions and approaches, MANAGE, Hyderabad.

[20].Savas, E.S. (1987). Privatization: the key to better government. Chatham House Publisher, New Jersy. 3-1. 